\title{
A STUDY OF DIGITAL INITIATIVE: SCOPE, CHALLENGES AND PERSPECTIVE OF DIGITAL ADAPTABILITY, DIGITAL TRANSPARENCY (AN EXPERIMENTAL STUDY)
}

\author{
Dr. D.V. Honagannavar \\ Principal, KLE Society's J G College of Commerce, Hubballi, \\ Karnataka, India \\ Vittal Bhat \\ Assistant Professor, KLE Society's J G College of Commerce, \\ Hubballi, Karnataka, India
}

\begin{abstract}
Digital may be a campaign launched by the government of India to make sure the Government's services area unit created obtainable to voters electronically by improved on-line infrastructure and by increasing web connectivity or by creating the country digitally sceptre within the field of technology.

The initiative includes plans to attach rural areas with high-speed web networks. Digital Republic of India consists of three core components: the event of secure and stable digital infrastructure, delivering government services digitally, and universal digital acquirement.

Digitalization is a word that defines the future. It aims to bridge the gap between the digital haves and have - not by using technology for citizen. India is a country where most of the population resides in villages; hence challenge is data illiteracy and adaptability. In this paper the researcher has collected a feedback from people in whom $75.7 \%$ of the respondents were young adult, 19.3\% were adult and 5\% were old. This study aims to understand the aspects such as digital literacy, accessibility, adaptability of the people. Transparency being an important factor, the study throws light on whether there is any scope of digitalization in India in future.

It is understood from the study that people are effective in using digital devices and digital services. People are comfortable in accessing online services and found online transactions easy in execution but one or the other factors have restricted them from doing online transactions. Some of the factors being lack of security, lack of interest, digital illiteracy and difficulty in adaptability. Study revealed that online payment transactions are safe, transparent and very much reliable. It is understood from the study that there is somewhat difficulty in implementing digitalization in India but there is sufficient scope in future.
\end{abstract}


Keywords: scope for Digitalization, Digital literacy, digital adaptably, digital transparency

Cite this Article: Dr. D.V. Honagannavar and Vittal Bhat, A Study of Digital Initiative: Scope, Challenges and Perspective of Digital Adaptability, Digital Transparency (An Experimental Study), International Journal of Advanced Research in Engineering and Technology, 10(1), 2019, pp 169-180.

http://iaeme.com/Home/issue/IJARET?Volume=10\&Issue $=1$

\section{INTRODUCTION}

We live in a world where everything is available at our fingertips; just a click away may it be groceries, apparels, gadgets. There has been a shift from a knowledge based society to a Technology based society. Digitalization is a word that defines the future. It aims to bridge the gap between the digital haves and have - not by using technology for citizen. Digital Republic of Asian nation stands for remodelling India into a digitally scattered information economy. Digital India sets pace for a makeover that shall change the face of the entire nation, impacting cities, towns, villages everywhere. The objective is to bring transformation in to reality i.e.: "Digital India: Power to Empower."

Although, the pace at which digital technology is evolving and transforming rapidly, in a country like India where most of the population resides in villages, is it fully possible to transform their lives as well, the challenge being data illiteracy and adaptability. Digital attainment is that the set of competencies needed for full participation in a very data society.

It includes skills, and characters involving the economical use of digital devices such as smart phones devices, phablets, tablets, laptops and desktop PCs for purposes of communication, expression, collaboration and support. Adaptability is additional very important to success than ever: amendment goes to happen whether or not you pursue it or not. Society succeeds when they adapt to changes and incorporate new technology into culture and regular operations. The internet has integrated deeply in global life. However, the internet remains young enough to have sharp contradictions and competing visions that our age must attempt to resolve. The adaptability of people towards this feature is a question that remains unanswered. The government of India has been making efforts to bridge the gap to help citizens take advantage of this initiative. Digital transformation reshapes every aspect of life. As digital technology continues to evolve, transparency is an essential component of building trust with people. The immediacy and accessibility of the web makes it a perfect medium for transparency. While people need to be aware of the possible risks of internet and benefits of increased transparency. This study aims to understand the aspects such as digital literacy, accessibility, adaptability of the people. Transparency being an important factor, there is necessity to understand whether there is any scope of digitalization in India.

\section{LITERATURE REVIEW}

According to Himakshi Goswami (2016), "Digital India stands for transforming India into a digitally empowered knowledge economy. It is Associate in nursing initiative of state of Asian nation to integrate the Government Departments and the people of India. It aims at ensuring that the Government services are made available to citizens electronically by reducing paper work."

Mehek Gulati (2016), in her paper "Digital India" is an initiative of the Central Government of India "concluded that it is designed to transform India into a global digitized hub" by renewing a summation digital sector of Asian nation with the assistance of up digital property and talent sweetening and varied different incentives to create the country digitally scattered 
A Study of Digital Initiative: Scope, Challenges and Perspective of Digital Adaptability, Digital Transparency (An Experimental Study)

within the field of technology. Further the paper conjointly highlights the opportunities that may pave the means for achieving the program's aim of creating Asian nation the popular alternative for digital activities by each international and domestic investors Associate in Nursing conjointly however way the "Digital India" model will persuade be an attraction for the investors to take a position within the sectors that square measure nevertheless to realize their full potential in India.

According to Dr Uma Narang, Digital India is the outcome of many innovations and technological advancements. These remodel the lives of individuals in some ways and can empower the society in a very higher manner. The 'Digital India' programme, will emerge new progressions in every sector and will generate innovative endeavours for Next. The motive behind the construct is to make participative, transparent and responsive system. The Digital India drive is a dream project of the Indian Government to remodel India into a knowledgeable economy and digitally empowered society.

Jyoti Siwach \& Dr. Amit Kumar (2015), in their paper concluded that Digital India, the dream project of the government and a blessing for the citizens, could help in connecting the dots of various comes, past and present, to bring India to a global platform. The Digital India vision aims to transform our country into a digital economy with participation from citizens and businesses. This initiative can make sure that all government services and knowledge square measure obtainable anyplace, anytime, on any device that's easy-to-use, seamless, highlyavailable and secured. The Digital Republic of India program is simply the start of a digital revolution, once enforced properly it'll open varied new opportunities for the voters.

According to Rahul Midha (2016), in the twenty-first century, one of the most important technologies is the power of the digitization. Digital Republic of Asian country may be a programme to remodel India into a digitally authorized society and data economy. It consists of three core components as follows- The creation of digital infrastructure, delivering services digitally and Digital literacy.

According to Neeru Gupta and Kawaldeep Arora, the world has transformed from knowledge savvy to techno knowledge savvy. Digital indicates to electronic technology that generates, stores and processes data. It is keep in a very virtual central repository which will be accessed anytime, anywhere, through established protocols. Digital Technologies include Cloud Computing and Mobile Applications.

\section{OBJECTIVES}

- To understand the digital literacy and adaptability in people.

- To examine the views of people regarding digital transparency and security

- To understand the insights of people with reference to scope for digitalization in India

\section{NEED FOR THE STUDY}

We are living in a world where everything is available at our fingertips; just a click away may it be groceries, apparels, gadgets. It is observed that digital technology is evolving and transforming rapidly in India, but most of the population resides in villages. Hence the challenge is how to make them digital literate and make them fast to adapt to changing world. Digital literacy includes knowledge, skills, and behaviours involving the effective use of digital devices such as smart phones, tablets, laptops and desktop PCs for purposes of communication, expression and advocacy. The adaptability of people towards digitalization is a question that remains unanswered. As digital technology continues to evolve, transparency becomes an essential component of building trust with people. Hence there is need to understand about the present status and scope for digitalization in future. 


\section{RESEARCH METHODOLOGY}

The study is conducted to understand the views of the respondents about Digital literacy, adaptability, transparency and Scope for digitalization in India. The total population size is 600 which are the privilege customers of different retail out lets. The data is analysis is done by using independent sample $t$ test and frequencies.

\section{Data analysis \& interpretation}

Table 1 Respondents Age Group

\begin{tabular}{|c|c|c|c|c|}
\hline & Frequency & Percent & Valid Percent & $\begin{array}{c}\text { Cumulative } \\
\text { Percent }\end{array}$ \\
\hline Valid Below 40 & 227 & 75.7 & 75.7 & 75.7 \\
$41-60$ & 58 & 19.3 & 19.3 & 95.0 \\
61 and Above & 15 & 5.0 & 5.0 & 100.0 \\
Total & 300 & 100.0 & 100.0 & \\
\hline
\end{tabular}

Interpretation: $75.7 \%$ of the respondents were young adult, $19.3 \%$ are adult and $5 \%$ are old

Table 2: Respondents Gender

\begin{tabular}{|c|c|c|c|c|}
\hline & Gender \\
\hline Valid Male & 164 & 54.7 & 54.7 & 54.7 \\
Female & 136 & 45.3 & 45.3 & 100.0 \\
Total & 300 & 100.0 & 100.0 & \\
\hline
\end{tabular}

Interpretation: $54.7 \%$ of the respondents are Male and $45.3 \%$ are Female

Table 3: Effectiveness in using digital devices

\begin{tabular}{|c|c|c|c|c|c|c|}
\hline \multicolumn{6}{|c|}{ One-Sample Statistics } & \\
\hline & & $\mathrm{N}$ & Mean & Std. Deviation & Std. Error Mean & \\
\hline $\begin{array}{l}\text { Effectiveness in using digital } \\
\text { devices such as Smart phones } \\
\text { Desktop and Laptop }\end{array}$ & & 300 & 3.77 & 1.037 & .060 & \\
\hline \multicolumn{7}{|c|}{ One-Sample Test } \\
\hline \multicolumn{7}{|c|}{ Test Value $=3$} \\
\hline \multirow{2}{*}{ T } & \multirow{2}{*}{ Df } & \multirow{2}{*}{\multicolumn{2}{|c|}{ Sig. (2-tailed) }} & \multirow{2}{*}{ Mean Difference } & \multicolumn{2}{|c|}{$\begin{array}{l}95 \% \text { Confidence Interval of the } \\
\text { Difference }\end{array}$} \\
\hline & & & & & Lower & Upper \\
\hline
\end{tabular}


A Study of Digital Initiative: Scope, Challenges and Perspective of Digital Adaptability, Digital Transparency (An Experimental Study)

One-Sample Test

\begin{tabular}{|l|c|c|c|c|c|c|}
\hline & \multicolumn{9}{|c|}{ Test Value =3 } \\
\cline { 2 - 7 } & & & & & \multicolumn{2}{c|}{ 95\% Confidence Interval of the } \\
Difference
\end{tabular}

Interpretation: It is understood that majority of the respondents are effective in using digital devices such as Smart phones, Desktop Computer and Laptops.

Table 4: Proficiency in using digital services

\begin{tabular}{|l|c|c|c|c|}
\hline & $\mathrm{N}$ & Mean & Std. Deviation & Std. Error Mean \\
\hline $\begin{array}{l}\text { Proficiency in using digital } \\
\text { services like E-mail, MS Office } \\
\text { and Google Services }\end{array}$ & 300 & 3.66 & 1.138 & .066 \\
\hline
\end{tabular}

One-Sample Test

\begin{tabular}{|c|c|c|c|c|c|c|}
\hline & \multicolumn{6}{|c|}{ Test Value $=3$} \\
\hline & \multirow{2}{*}{$\mathrm{T}$} & \multirow{2}{*}{ Df } & \multirow{2}{*}{ Sig. (2-tailed) } & \multirow{2}{*}{ Mean Difference } & \multicolumn{2}{|c|}{$\begin{array}{l}95 \% \text { Confidence Interval of the } \\
\text { Difference }\end{array}$} \\
\hline & & & & & Lower & Upper \\
\hline $\begin{array}{l}\text { Proficiency in using digital } \\
\text { services like E-mail, MS Office } \\
\text { and Google Services }\end{array}$ & 10.099 & 299 & .000 & .663 & .53 & .79 \\
\hline
\end{tabular}

Interpretation: It is understood that majority of the respondents are proficient in using digital services like E-Mail, MS Office and Google. 
Dr. D.V. Honagannavar and Vittal Bhat

Table 5: Comfort level in accessing e- reading materials

One-Sample Statistics

\begin{tabular}{|l|c|c|c|c|}
\hline & $\mathrm{N}$ & Mean & Std. Deviation & Std. Error Mean \\
\hline $\begin{array}{l}\text { Comfort level in accessing an e- } \\
\text { newspaper, e-magazine, e-book } \\
\text { or an e-journal }\end{array}$ & 300 & 3.42 & 1.046 & .060 \\
\hline
\end{tabular}

One-Sample Test

\begin{tabular}{|c|c|c|c|c|c|c|}
\hline & \multicolumn{6}{|c|}{ Test Value $=3$} \\
\hline & \multirow{2}{*}{$t$} & \multirow{2}{*}{ Df } & \multirow{2}{*}{ Sig. (2-tailed) } & \multirow{2}{*}{ Mean Difference } & \multicolumn{2}{|c|}{$\begin{array}{l}95 \% \text { Confidence Interval of the } \\
\text { Difference }\end{array}$} \\
\hline & & & & & Lower & Upper \\
\hline $\begin{array}{l}\text { Comfort level in accessing an e- } \\
\text { newspaper, e-magazine, e-book } \\
\text { or an e-journal }\end{array}$ & 6.902 & 299 & .000 & .417 & .30 & .54 \\
\hline
\end{tabular}

Interpretation: It is understood that majority of the respondents are comfortable in accessing enews paper, e-magazine, e-book or an e-journal.

Table 6: Comfort level in using online services

One-Sample Statistics

\begin{tabular}{|l|c|c|c|c|}
\hline & $\mathrm{N}$ & Mean & Std. Deviation & Std. Error Mean \\
\hline $\begin{array}{l}\text { Comfort level in using online } \\
\text { services such as e-Booking/ e- } \\
\begin{array}{l}\text { Reservation, e-Shopping and e- } \\
\text { Banking }\end{array}\end{array}$ & 300 & 3.56 & 1.168 & .067 \\
\hline
\end{tabular}

One-Sample Test

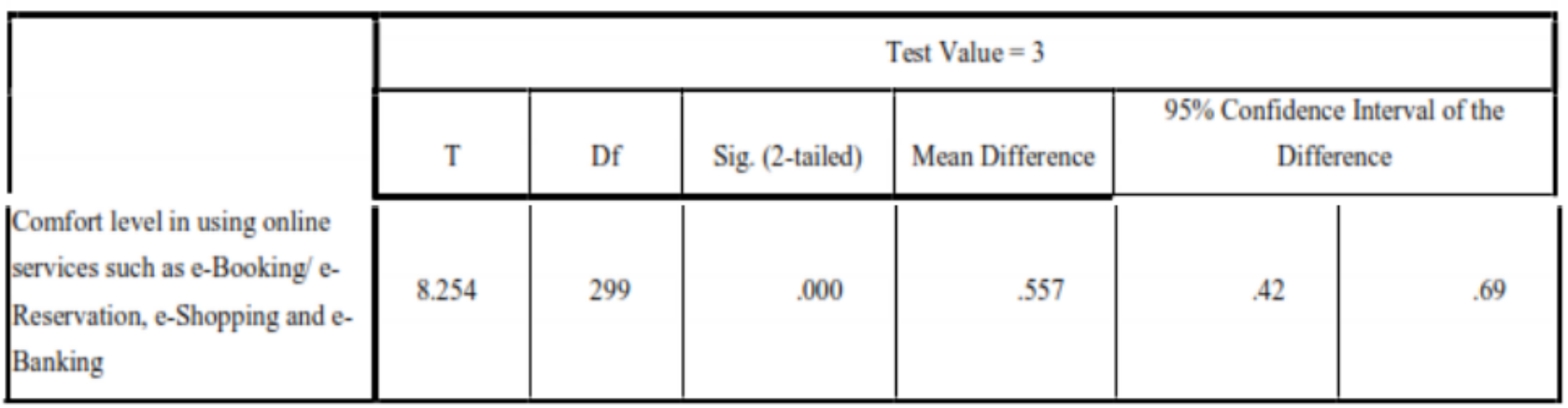

Interpretation: It is understood that majority of the respondents are comfortable in using online services such as e-booking/reservation, e-shopping and e-banking. 
A Study of Digital Initiative: Scope, Challenges and Perspective of Digital Adaptability, Digital Transparency (An Experimental Study)

Table 7: Level of Difficulty may face in executing online transactions / purchases

One-Sample Statistics

\begin{tabular}{|l|c|c|c|c|}
\hline & $\mathrm{N}$ & Mean & Std. Deviation & Std. Error Mean \\
\hline $\begin{array}{l}\text { Level of Difficulty may face in } \\
\text { executing online transactions/ } \\
\text { purchases }\end{array}$ & 300 & 3.43 & 1.115 & .064 \\
\hline
\end{tabular}

One-Sample Test

\begin{tabular}{|l|c|c|c|c|c|c|}
\hline & \multicolumn{9}{|c|}{ Test Value = 3 } \\
\cline { 2 - 7 } & & & & & \multicolumn{2}{c|}{ 95\% Confidence Interval of the } \\
Difference
\end{tabular}

Interpretation: It is understood that majority of the respondents have found online transactions / purchases easy in execution.

Table 8: Speed of adaptability to digitization

\begin{tabular}{|l|c|c|c|c|}
\hline & $\mathrm{N}$ & Mean & Std. Deviation & Std. Error Mean \\
\hline $\begin{array}{l}\text { Adaptability Speed to E- } \\
\text { banking, E-Commerce and } \\
\text { digitalization }\end{array}$ & 300 & 3.33 & 1.015 & .059 \\
\hline
\end{tabular}

\begin{tabular}{|c|c|c|c|c|c|c|}
\hline \multicolumn{7}{|c|}{ One-Sample Test } \\
\hline & \multicolumn{6}{|c|}{ Test Value $=3$} \\
\hline & \multirow{2}{*}{$\mathrm{T}$} & \multirow{2}{*}{ Df } & \multirow{2}{*}{ Sig. (2-tailed) } & \multirow{2}{*}{ Mean Difference } & \multicolumn{2}{|c|}{$\begin{array}{l}95 \% \text { Confidence Interval of the } \\
\text { Difference }\end{array}$} \\
\hline & & & & & Lower & Upper \\
\hline $\begin{array}{l}\text { Adaptability Speed to E- } \\
\text { banking, E-Commerce and } \\
\text { digitalization }\end{array}$ & 5.575 & 299 & .000 & .327 & .21 & .44 \\
\hline
\end{tabular}

Interpretation: It is understood that majority of the respondents have found themselves fast in adapting to e-banking, e-commerce and digitalization. 
Dr. D.V. Honagannavar and Vittal Bhat

Table 9: Factors that might have restricted people from doing online transactions

Factors that might have restricted people from doing online transactions

\begin{tabular}{|l|r|r|r|r|}
\hline & Frequency & Percent & Valid Percent & $\begin{array}{c}\text { Cumulative } \\
\text { Percent }\end{array}$ \\
\hline Valid Fear of Technology & 22 & 7.3 & 7.3 & 7.3 \\
Lack of Security & 71 & 23.7 & 23.7 & 31.0 \\
Digital Illiteracy & 32 & 10.7 & 10.7 & 41.7 \\
Linguistic Barrier & 13 & 4.3 & 4.3 & 46.0 \\
Lack of Interest & 42 & 14.0 & 14.0 & 60.0 \\
Difficulty in Adaptability & 31 & 10.3 & 10.3 & 70.3 \\
None of these & 89 & 29.7 & 29.7 & 100.0 \\
Total & 300 & 100.0 & 100.0 & \\
\hline
\end{tabular}

Interpretation: $70.3 \%$ of the respondents are of the view that one or the other factors have restricted them from doing online transactions. $23.7 \%$ are of the view that Lack of security has kept them away from these transactions. Few respondents are of the view that lack of interest, digital illiteracy and difficulty in adaptability are the reasons for not doing online transactions. For $29.7 \%$ of them no factor has restricted them from doing online transactions.

Table 10: View on Transparency in digital transactions

\begin{tabular}{|} 
Vlew on Transparency in digital transactions \\
\begin{tabular}{|l|c|c|c|c|}
\hline & Frequency & Percent & Valid Percent & $\begin{array}{c}\text { Cumulative } \\
\text { Percent }\end{array}$ \\
\hline Valid Not Transparent & 33 & 11.0 & 11.0 & 11.0 \\
Partially Transparent & 175 & 58.3 & 58.3 & 69.3 \\
Completely Transparent & 92 & 30.7 & 30.7 & 100.0 \\
Total & 300 & 100.0 & 100.0 & \\
\hline
\end{tabular}
\end{tabular}

Interpretation: $58.3 \%$ of the respondents are of the view that digital transactions are partially transparent and $11 \%$ have said that digital transactions are not at all transparent. Hardly $30.7 \%$ of them are of the view that digital transactions are completely transparent. 
A Study of Digital Initiative: Scope, Challenges and Perspective of Digital Adaptability, Digital Transparency (An Experimental Study)

Table 11: View about Safety Level in online payment transactions

\begin{tabular}{|l|c|c|c|c|}
\hline \multicolumn{1}{|c|}{ One-Sample Statistics } \\
\hline & $\mathrm{N}$ & Mean & Std. Deviation & Std. Error Mean \\
\hline $\begin{array}{l}\text { View about Safety Level in } \\
\text { online payment transactions }\end{array}$ & 300 & 3.38 & .927 & .053 \\
\hline
\end{tabular}

\begin{tabular}{|l|c|c|c|c|c|c|}
\hline & \multicolumn{9}{|c|}{ One-Sample Test } \\
\cline { 2 - 7 } & & & & & \multicolumn{2}{c|}{ T5\% Confidence Interval of the } \\
Difference
\end{tabular}

Interpretation: Majority of the respondents are of the view that online payment transactions are safe.

Table 12: View on Reliability Level of online transactions

\begin{tabular}{|l|c|c|c|c|}
\hline & $\mathrm{N}$ & Mean & Std. Deviation & Std. Error Mean \\
\hline $\begin{array}{l}\text { View on Reliability Level of } \\
\text { online transactions }\end{array}$ & 300 & 3.65 & .850 & .049 \\
\hline
\end{tabular}

\begin{tabular}{|c|c|c|c|c|c|c|}
\hline \multicolumn{7}{|c|}{ One-Sample Test } \\
\hline & \multicolumn{6}{|c|}{ Test Value $=3$} \\
\hline & \multirow{2}{*}{$t$} & \multirow{2}{*}{ Df } & \multirow{2}{*}{ Sig. (2-tailed) } & \multirow{2}{*}{ Mean Difference } & \multicolumn{2}{|c|}{$\begin{array}{l}95 \% \text { Confidence Interval of the } \\
\text { Difference }\end{array}$} \\
\hline & & & & & Lower & Upper \\
\hline $\begin{array}{l}\text { View on Reliability Level of } \\
\text { online transactions }\end{array}$ & 13.316 & 299 & .000 & .653 & .56 & .75 \\
\hline
\end{tabular}

Interpretation: Majority of the respondents are of the view that online transactions are very reliable. 
Dr. D.V. Honagannavar and Vittal Bhat

Table 13: Scope of mobile based payment technologies in future for a cashless economy

One-Sample Statistics

\begin{tabular}{|l|c|c|c|c|}
\hline & $\mathrm{N}$ & Mean & Std. Deviation & Std. Error Mean \\
\hline $\begin{array}{l}\text { Scope of mobile based payment } \\
\text { technologies in future for } \\
\text { cashless economy }\end{array}$ & 300 & 3.76 & 1.005 & .058 \\
\hline
\end{tabular}

One-Sample Test

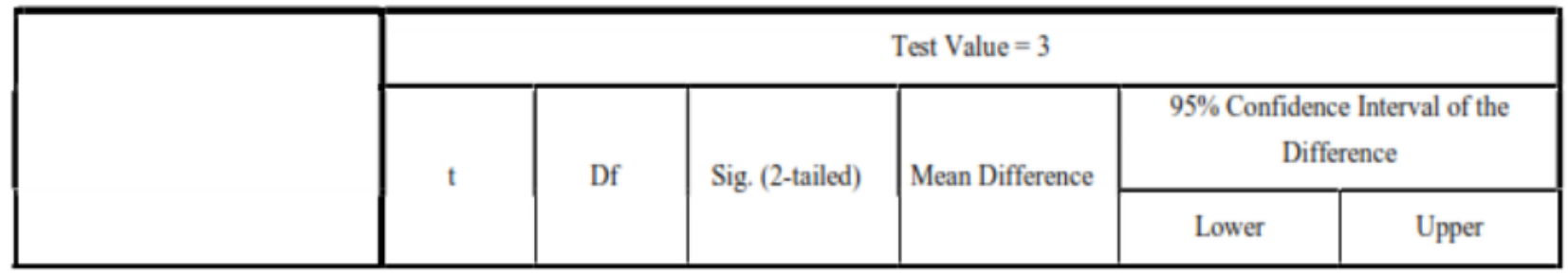

Table 14: Scope for digitization in India in future

\begin{tabular}{|l|c|c|c|c|}
\hline \multicolumn{1}{|c|}{ One-Sample Statistics } \\
\hline & $\mathrm{N}$ & Mean & Std. Deviation & Std. Error Mean \\
\hline $\begin{array}{l}\text { Scope for digitization in India } \\
\text { in future }\end{array}$ & 300 & 3.81 & 1.159 & .067 \\
\hline
\end{tabular}

One-Sample Test

\begin{tabular}{|c|c|c|c|c|c|c|}
\hline & \multicolumn{6}{|c|}{ Test Value $=3$} \\
\hline & \multirow[b]{2}{*}{$\mathrm{T}$} & \multirow[b]{2}{*}{ Df } & \multirow[b]{2}{*}{ Sig. (2-tailed) } & \multirow[b]{2}{*}{ Mean Difference } & \multicolumn{2}{|c|}{$\begin{array}{l}95 \% \text { Confidence Interval of the } \\
\text { Difference }\end{array}$} \\
\hline & & & & & Lower & Upper \\
\hline $\begin{array}{l}\text { Scope for digitization in India in } \\
\text { future }\end{array}$ & 12.156 & 299 & .000 & .813 & .68 & .95 \\
\hline
\end{tabular}

Interpretation: It is understood that there is sufficient scope for digitalization in India in future.

\begin{tabular}{|c|c|c|c|c|c|c|}
\hline \multicolumn{7}{|c|}{ One-Sample Test } \\
\hline & \multicolumn{6}{|c|}{ Test Value $=3$} \\
\hline & \multirow[b]{2}{*}{$\mathrm{t}$} & \multirow[b]{2}{*}{ Df } & \multirow[b]{2}{*}{ Sig. (2-tailed) } & \multirow[b]{2}{*}{ Mean Difference } & \multicolumn{2}{|c|}{$\begin{array}{l}95 \% \text { Confidence Interval of the } \\
\text { Difference }\end{array}$} \\
\hline & & & & & Lower & Upper \\
\hline $\begin{array}{l}\text { Scope of mobile based payment } \\
\text { technologies in future for } \\
\text { cashless economy }\end{array}$ & 13.151 & 299 & .000 & .763 & .65 & .88 \\
\hline
\end{tabular}


A Study of Digital Initiative: Scope, Challenges and Perspective of Digital Adaptability, Digital Transparency (An Experimental Study)

Table 15: Digital India's proper implementation in India

\section{One-Sample Statistics}

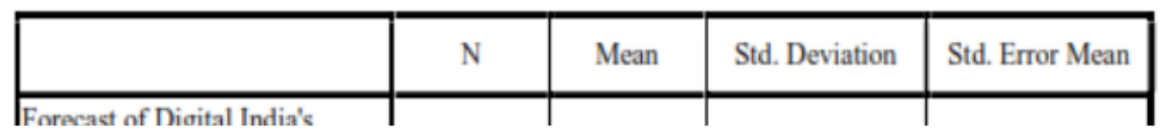

Table 16: Difficulty Level in implementation of digitization in India

One-Sample Statistics

\begin{tabular}{|l|c|c|c|c|}
\hline & $\mathrm{N}$ & Mean & Std. Deviation & Std. Error Mean \\
\hline $\begin{array}{l}\text { Difficulty Level in } \\
\text { implementation of digitization } \\
\text { in India }\end{array}$ & 300 & 2.74 & 1.001 & .058 \\
\hline
\end{tabular}

One-Sample Test

\begin{tabular}{|c|c|c|c|c|c|c|}
\hline & \multicolumn{6}{|c|}{ Test Value $=0$} \\
\hline & \multirow[b]{2}{*}{$\mathrm{t}$} & \multirow[b]{2}{*}{ Df } & \multirow[b]{2}{*}{ Sig. (2-tailed) } & \multirow[b]{2}{*}{ Mean Difference } & \multicolumn{2}{|c|}{$\begin{array}{l}95 \% \text { Confidence Interval of the } \\
\text { Difference }\end{array}$} \\
\hline & & & & & Lower & Upper \\
\hline $\begin{array}{l}\text { Difficulty Level in } \\
\text { implementation of digitization in } \\
\text { India }\end{array}$ & 47.401 & 299 & .000 & 2.740 & 2.63 & 2.85 \\
\hline
\end{tabular}

Interpretation: Majority of the respondents are of the opinion that proper implementation of digital India will happen by FY 2025.

Interpretation: It is understood that there is somewhat difficulty in implementing digitalization in India as per the information of majority of the respondents.

\section{CONCLUSIONS}

It is understood from the study that people are effective in using digital devices and are capable of using digital services as well. People are comfortable in accessing e-newspaper, e-magazine, e-book or an e-journal and online services such as e-booking/reservation, eshopping and e- banking. Majority of the respondents have found online transactions / purchases easy in execution but one or the other factors have restricted them from doing online transactions. Some of the factors being lack of security, lack of interest, digital illiteracy and difficulty in adaptability. At the same time it is found that people are fast in adapting to e-banking, e-commerce and digitalization.

Majority of the respondents are of the opinion that online payment transactions are safe, transparent and very much reliable. It is understood from the study that there is somewhat difficulty in implementing digitalization in India but there is sufficient scope in future. Proper implementation of digitalization India is expected to happen by FY 2025.

\section{REFERENCES}

[1] Himakshi Goswami, Opportunities and Challenges of Digital India Programme, International Education and Research Journal, Volume: 2, Issue: 11, Nov 2016. 
[2] Jyoti Siwach \& Dr. Amit Kumar, Vision of Digital India: Dreams comes True, IOSR Journal of Economics and Finance (IOSR-JEF), Volume 6, Issue 4. Ver. I, Jul. - Aug.2015, Pp 66-71.

[3] 3. Mehek Gulati, Digital India: Challenges \& Opportunities, BEST: International Journal of Management, Information Technology and Engineering, Vol. 4, Issue 10, Oct 2016, 1-4.

[4] Neeru Gupta and Kawaldeep Arora, Digital India :A Roadmap for the development of Rural India, International Journal Of Business Management, VOL.2(2), 2015, Pp 1333-1342.

[5] Rahul Midha, Digital India: Barriers \& Remedies, International Conference on Recent Inovations in Sciences, management, education and Technology. Pp 256-260.

[6] Hashem Hussein Al Attas, Effect of digital Literacy on information seeking behaviour among managers of telecommunication companies in Saudi Arabia, International Journal of Library \& Information Science, 8(2), 2019, pp. 01-08.

[7] Sudhir Kumar Sharma Vandana Lama Nidhi Goyal, Digital India: A Vision Towards Digitally Empowered Knowledge Economy, Volume: 5, Issue: 10, October 2015, Pp 715-716.

[8] The Making of Digital India, Department of Electronics \& Information Technology (DeitY), Ministry of Communications and Information Technology.

[9] Rao, S. S. (2005). Bridging digital divide: Efforts in India. Telematics and informatics, 22(4), 361-375.

[10] Thomas, P. N. (2012). Digital India: understanding information, communication and social change. SAGE Publications India.

[11] Odat, A. M. (2012, December). E-government in developing countries: Framework of challenges and opportunities. In 2012 International Conference for Internet Technology and Secured Transactions (pp. 578-582). IEEE.

[12] Ghosh, M. (2005). The public library system in India: challenges and opportunities. Library Review, 54(3), 180-191.

[13] Reji K Kollinal, Dr. John S Moolakkattu and Dr. Varghese Paul, Digital India - The Great Dream, International Journal of Computer Engineering and Technology 10(3), 2019, pp. 87-93

[14] Singh, J., \& Kaur, T. (2009). Future of Academic Libraries in India: challenges and opportunities. In A paper presented at the International Conference on Academic Libraries (ICAL) held at the University of Delhi, India (Vol. 52).

[15] Singh, S. (2010). Digital divide in India: Measurement, determinants and policy for addressing the challenges in bridging the digital divide. International Journal of Innovation in the Digital Economy (IJIDE), 1(2), 1-24. 